\title{
The Capacity and Institution Building Working Group of United Cities and Local Governments: Towards Improving Aid Effectiveness in the Local Government Sector $^{1}$
}

Commonwealth Journal of Local Governance

Issue 4: November 2009

http:/lepress.lib.uts.edu.au/ojs/index.php/cjlg

\section{Tim Kehoe}

Federation of Canadian Municipalities

UCLG CIB Working Group

Canada

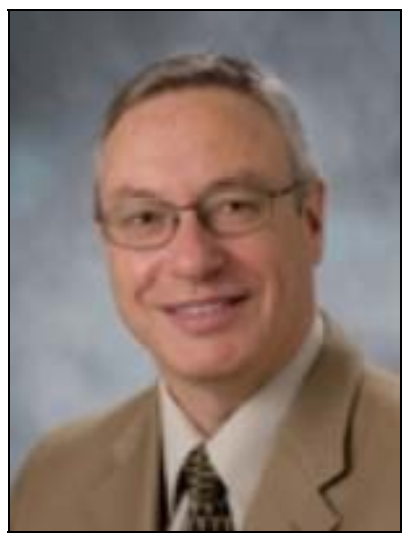

The United Cities and Local Governments (UCLG) Capacity and Institution Building (CIB) Working Group gather together professional practitioners of local government associations (LGAs) and individual local governments active in international cooperation, with the overall objective to improve the quality, coordination and alignment of their development cooperation interventions.

The Working Group is the successor of the CIB Platform, which existed for many years within the former International Union of Local Authorities (IULA) as an informal gathering of staff members of local government associations (LGAs) involved in the field of municipal international cooperation (MIC) and association capacity building (ACB). In addition to information exchange, the CIB Platform undertook specific

\footnotetext{
${ }^{1}$ This paper is a modified version of a case study published in the UCLG Position Paper on Aid Effectiveness in Local Government: Understanding the Link between Governance and Development, United Cities and Local Governments: Barcelona, November 2009 and was adopted at the UCLG World Council meeting in Guangzhou, China on November 13, 2009.
} 
initiatives such as a World Bank-funded program supporting ACB in several countries. In May 2004, the CIB was integrated into the structures of the newly-founded UCLG organisation, and its membership was expanded to also include staff members of international departments of cities active in international cooperation.

In 2007, the CIB members decided to bring greater structure and rigor to the group's work in order to ensure concrete results and increased aid effectiveness through better harmonization of the initiatives of local governments and their national associations. Terms of reference and a three-year work plan were adopted, and a project officer position was established in UCLG’s World Secretariat in Barcelona.

The CIB set out to tackle four main areas: (1) exchange of experiences, best practices and work methods; (2) program coordination to harmonize interventions and promote collaboration among LGA implementing agencies working in the same southern country or region; (3) preparation of technical papers to inform UCLG policy related to MIC and ACB and its advocacy with multilateral donor institutions; and (4) development of an international professional code for local government organizations involved in development cooperation.

The Chair of the Working Group is the Netherlands LGA's international arm, VNG International, with the Federation of Canadian Municipalities (FCM) as Vice-Chair.

\section{Information Sharing}

In the Working Group's annual meetings, members noted that a lack of information on each other's work in municipal international cooperation (MIC) and association capacity building (ACB) had led to duplication or overlap in programming. For example, two or more northern LGAs would be working in a given country with a southern LGA partner on the same topic without even being aware of the other's work. This, of course, has led to inefficiencies such as separate workshops being organized with the same partners around the same dates.

As an important first step towards harmonization of efforts, a CIB website was designed to foster information exchange and to identify opportunities for collaboration (United Cities and Local Governments 2009). The CIB website tracks "who is doing what and where" in terms of municipal development programmes (i.e. association capacity 
building, decentralized cooperation and municipal international cooperation) and maps the interventions of all CIB members and their main publications and tools. Within the website, a membership-only area has been created to enable online discussions and exchange of more sensitive documents, i.e. monitoring and evaluation tools, impact indicators, financial information and contact details.

\section{Program Coordination - Concrete Examples}

In addition to the regular exchange of information, the Working Group has selected five pilot countries in which CIB members have agreed to pay special attention to harmonizing their ACB and MIC programmes. In these countries (Mali, Ghana, Nicaragua, Burkina Faso and Zimbabwe), one CIB member together with the partner country LGA serve as the focal point for strengthening coordination and harmonization (Cites Unies France, Mali; VNG International, Ghana; Federation of Canadian Municipalities, Nicaragua; Union des Villes et Cites de Wallonie, Burkina Faso; Local Government Association (England and Wales), Zimbabwe). It was further agreed that the partners would work within program coordination guidelines adopted by the CIB at its annual meeting in July 2008. These guidelines outline a continuum of options ranging from straightforward documentation and sharing of information on each other's programs, to eliminating overlaps, identifying concrete opportunities for collaboration, and organizing with the southern LGA partner a formal table for dialogue with donors and implementing organisations. This could lead to using the outcome of projects of one organisation as the starting point for the project of another organisation, pooling expertise and financial resources for the technical assistance offered to the partner organisation(s), pooling local human resources, co-organising of workshops, development of joint information material, joint approaches to donor organisations, and so on.

Program coordination in the five pilot countries begins with the identification of possible overlap or duplication of activities. The lead CIB partner, together with the partner country LGA, assembles information on ACB and MIC activities and identifies opportunities for collaboration. The objective of these exchanges - mainly through coordination sheets and regular contact - is to be able to pool expertise and financial resources for technical assistance, local human resources, and the co-organization of workshops. For example, in Ghana, VNG International and the National Association of Local Authorities of Ghana (NALAG) undertook an analysis of current cooperation with 
its northern partners. Upon learning of the multiple interventions related to waste management in Ghana, VNG International, the German aid agency GTZ, and NALAG have harmonized their efforts such that they are enlarging the local tax base, while improving municipal waste management services.

Waste collection falls under the jurisdiction of District Assemblies in Ghana, yet despite many donor interventions over several years, collecting waste remained a challenge for the Districts. NALAG, along with four District Assemblies with a longstanding relationship with four local governments in the Netherlands, decided to work towards fee collection for refuse removal. They harmonized their efforts with GTZ, which was supporting a project to install District Database Systems across the country. Through their collaboration these systems were designed to support information requirements for the fee collection for refuse removal, such as data related to the amount of refuse that could be expected, and mapping of areas to be served. All parties have been working together on other elements of the program as well, such as capacity development, revenue generation, and awareness raising among local elected officials and staff (United Cities and Local Governments 2009, p. 43).

Zimbabwe has also recently become a pilot country for program coordination, whereby a number of CIB partners, along with the Commonwealth Local Government Forum (CLGF), are working towards an international local government response to support the sector in Zimbabwe. Local government in Zimbabwe received an overwhelming democratic mandate in the 2008 local elections and there is, therefore, a strong case that it should be viewed as separate from central government and be accorded proper legitimacy and support from donors in line with its democratic mandate so as to maintain the grassroots momentum for democratic change.

The CIB working group has agreed that the Local Government Association of England and Wales (LGA), working with CLGF, should take the lead in coordinating wider international support, notably with the Dutch VNG, the Swedish SKF, and the Canadian FCM which have maintained a strong interest in supporting local governance in Zimbabwe. Following discussions with the Urban Councils Association of Zimbabwe (UCAZ), and based on needs assessments carried out over recent months, coordination will focus on five core areas for short-to-medium term support, including: 
- Local government input into the constitutional review process;

- Councillor and staff training;

- Capacity building of the local government association UCAZ;

- Council-to-council partnerships targeted at meeting skills shortages and improving infrastructure and essential local services; and

- Community-based reconciliation (a key mechanism to encourage political healing that promotes reconciliation and community justice).

Coordination does not only occur within the selected pilot cases. The connections made between organizations through the CIB Working Group have enabled coordination to become more frequent and gives some inspiring examples of harmonization. For example, in February 2009, FCM and VNG International co-organized with the Association of Cities of Vietnam and UCLG/ASPAC the $3^{\text {rd }}$ Asia Pacific Local Government Association Partners Workshop on Financial Sustainability and Advocacy in Hanoi, Vietnam. ${ }^{2}$ This collaboration facilitated the participation of a larger pool of LGAs (14 LGAs from the region) as well as engaged expert capacity building resources from the two northern partners on two themes: policy advocacy and financial sustainability planning.

In addition, CIB members have found opportunities to coordinate the planning of projects and programs in non-pilot countries. For example, when FCM and VNG International learned that they both had a common partner in Cambodia, the National Association of Communes and Sangkats (NLC/S), they made a concerted effort to design projects in a coordinated way. The strategic plan of NLC/S was taken as the point of reference for design, with each organization providing technical assistance in areas of comparative expertise, i.e. VNG International on member services and financial sustainability, and FCM on developing the systems, guidelines and tools to perform more effective communications and advocacy on behalf of its members. This has resulted in better coordinated, more efficient interventions by the two northern partners and greater ownership of the initiatives on the part of NLC/S.

\footnotetext{
${ }^{2}$ This workshop built on a similarly co-organized workshop with associations in Asia in Manila, May 2008.
} 


\section{Policy and Advocacy}

The CIB Working Group serves as a technical resource base for UCLG on issues related to MIC and ACB, for example in relation to pursuit of the Millennium Development Goals. In this capacity, it has been supporting the development of three policy papers: (1) aid effectiveness and local government, (2) local government and development cooperation, ${ }^{3}$ and (3) local government and economic stimulus. ${ }^{4}$ These papers are meant to inform the practice of UCLG members and provide a policy basis for dialogue with the international donor community and multilateral institutions.

The UCLG Position Paper on Aid Effectiveness in Local Government is a good case in point. The 2005 Paris Declaration on Aid Effectiveness, signed by all OECD countries and endorsed by many developing countries, reflects a policy consensus that is shaping the way that donors define their priority sectors and focus countries, and select the mechanisms through which they deliver aid. Although potentially significantly impacted by this new approach to aid delivery, local government was not included in these policy discussions. The position paper calls for the full acknowledgement of local and regional governments as development partners and outlines a number of policy recommendations directed to donors and central governments as well as to local governments and their associations on improving aid effectiveness.

Already we are beginning to see modest progress. For example, the Accra Agenda for Action (AAA), which was the result of the mid-term 3rd High Level Forum on Aid Effectiveness in Accra, Ghana (2-4 September, 2008), includes explicit recognition of the role of local governments in the development of national development policies. The AAA also recognizes the need to support capacity-building initiatives of local authorities and emphasizes the importance of local resources in the provision of technical cooperation. In recognition of the value brought by local governments to these policy discussions, UCLG has been invited to become a permanent member of the OECD/DAC Working Party on Aid Effectiveness and it will also be working with the UN Development Cooperation Forum in an advisory capacity.

\footnotetext{
${ }^{3}$ This paper will present the experience and expertise of local and regional governments in the area of decentralized cooperation and outline principles and guidelines for the international action of local governments and their associations in the field of development cooperation.

${ }^{4}$ UCLG has collected case studies from its developing country network on the impact of the global financial crisis on local and regional governments. This paper will help support international advocacy, arguing for increased investment at the local level by national governments and international institutions (i.e. UN, financial institutions and development banks).
} 


\section{Challenges in Coordination}

Even though work has progressed since 2007, the CIB members face significant challenges to ensure true harmonization of efforts. First of all, most northern LGAs receive funds for MIC and ACB programmes through their respective Ministries of Foreign Affairs or Agencies responsible for official development assistance. Due to the often rigid regulations that accompany these funds (i.e. specific reporting requirements, eligible thematic areas of focus, geographic concentration and types of capacity building assistance), it is not always possible to coordinate with other LGAs or to pool financial and human resources. This creates a gap between the enthusiasm of CIB members to coordinate and the reality of programming and contractual restrictions. In order to increase aid effectiveness, donors should allow for increased flexibility in the implementation of ODA programs delivered through LGAs.

Secondly, to ensure real ownership of the programmes, coordination of northern partner interventions should ideally be initiated and led by the southern partner LGAs and local governments. Clearly, a stronger southern LGA voice is needed at the CIB table, but additional financial resources are required to facilitate the participation of partner country/regional LGAs. It is important to raise donors' appreciation of the importance of providing funding for partner country participation in multilateral committees and forums addressing aid effectiveness.

Finally, CIB members themselves also need to invest greater efforts and resources in the sharing of information and program coordination. While LGAs in both the south and the north are growing in their understanding and appreciation of the principles of aid effectiveness, much more must be done to change entrenched approaches. While this improvement of understanding leads to good results in local-level projects, they often do not add up to broader sectoral and country-level impacts due to a lack of alignment with national development priorities and harmonization with the investments of other actors.

Much has been done within the international local government family to work toward greater coherence in the implementation of MIC and ACB programmes. The CIB Working Group has been, and continues to play, a key role in the identification of any overlap and opportunities for cooperation as well as in providing an opportunity for strengthening relations amongst its members. The aim is to build on the modest but real 
successes to date through refining the CIB coordination of development cooperation including new tools and indicators to measure our work - in order to more successfully apply the principles of aid effectiveness.

For more information about the CIB Working Group, contact Ms. Renske Steenbergen at r.steenbergen@cities-localgovernments.org.

\section{References:}

Capacity and Institution Building Working Group 2009, United Cities and Local Governments, Barcelona, accessed 26 November 2009, <http://www.cities-localgovernments.org/cib>.

United Cities and Local Governments 2009, UCLG Position Paper on Aid Effectiveness in Local Government: Understanding the Link between Governance and Development, UCLG, Barcelona.

\section{Appendix 1: Commonwealth Members of the CIB Working Group}

- Kenya Association of Local Government Authorities of Kenya (ALGAK)

- South Africa South African Local Government Association (SALGA)

- Pakistan Local Councils Association of the Punjab (LCAP)

- United Kingdom Local Government Association (LGA)

- Canada Federation of Canadian Municipalities (FCM) 